\title{
A new combination and lectotypification for a Cuban Polystichopsis (Dryopteridaceae)
}

\author{
CARLos SÁnchez
}

Jardín Botánico Nacional, Carretera del Rocia KM 3.5, Calabazar, CP 19230, Cuidad Habana, Cuba; e-mail: atalopteris@gmail.com

\begin{abstract}
A new combination is provided for the Cuban species Phegopteris sericea in the genus Polystichopsis: Polystichopsis sericea. Also, a lectotype is designated for this species.
\end{abstract}

Key Words: Eupolypods I, ferns, taxonomy, West Indies.

During my studies of ferns and lycophytes for the Flora of Cuba, I found a species of Polystichopsis that was originally described in Phegopteris by Eaton (1860). Later, it was treated as variety of both Dryopteris lurida Jenman ex Underw. (Christensen, 1920) and D. chaerophylloides (Poir.) C. Chr. (Christensen, 1936). This species belongs to Polystichopsis because of its creeping rhizomes, distichous leaves, decompound laminae, and long straightish, white hairs on the leaves. It seems readily distinct from other species of Polystichopsis by the narrow form of its blade and long (1-2 mm) hairs on the rachises and costa abaxially. In particular, it differs from the similar P. chaerophylloides, which also occurs in Cuba, by more divided laminae, smaller and narrower segments, margins sometimes merely sinuate, and the teeth less acute. Compared to $P$. chaerophylloides, the lateral veins are less evident and the laminae are thinner and brownish when dry, not deep green. Geographically, $P$. chaerophylloides is widespread in the Caribbean region, but the taxon combined below is endemic to eastern Cuba and grows between 750-1000 m. Because the Cuban plant belongs to Polystichopsis and seems amply distinct from other species in the genus, it is recognized here at the rank of species. This new combination is needed for an upcoming monograph of the genus by Robbin Moran and Jefferson Prado.

\section{New combination and lectotypification}

Polystichopsis sericea (Mett. ex D. C. Eaton) C. Sánchez, comb. nov. Phegopteris sericea Mett. ex D. C. Eaton, Mem. Amer. Acad. Arts n.s. 8:
208. 1860. Dryopteris lurida Jenman ex Underw. \& Maxon var. sericea (Mett.) C. Chr., Kongel. Danske Vidensk. Selsk. Skr., Naturvidensk. Math. Afd., ser. 8, 6: 107. 1920. Dryopteris chaerophylloides (Poir.) C. Chr. var. sericea (Mett. ex D. C. Eaton) C. Chr., Kongl. Svenska Vetensk. Acad. Handl., n.s. 16(2): 36. 1936. Polystichopsis lurida (Jenman ex Underw. \& Maxon) C. V. Morton var. sericea (Mett ex D.C. Eaton) Duek., Adansonia 11: 724. 1971. Type: Cuba. Santiago de Cuba: La Guinea, Sep 1859, C. Wright 1054 (lectotype, designated here: YU barcode YU.000773; isolectotypes: B barcode B200059122, BM barcode BM001079698, K barcode K000590367, GH barcodes GH000211761, GH00415549, MO, accession no. 1872629, P barcode P01443882, UC barcode UC35419).

Distribution.-Eastern Cuba (Sierra Maestra Range); rocky woods, $750-1000 \mathrm{~m}$.

\section{Literature Cited}

Christensen, C. 1920. A monograph of the genus Dryopteris, Part II. The tropical American bipinnate-decompound species. Kongelige Danske Videnskabernes Selskabs Skrifter, Naturvidenskabelig of. Mathematiske Afdeling, ser. 8, 6: 3-132.

. 1936. The collection of Pteriophyta made in Hispaniola by E. L. Ekman 1917 and 1924-1930. Kungliga Svenska Vetenskapsakademiens Handlingar, new series 16(2): $1-93+20$ plates.

Eaton, D. C. 1860. Filices Wrightianae et Fendlerianae, nempe Wrightianae Cubenses et Fendlerianae Venezuelanae (nonnullis Panamensibus, etc., ex coll. A. Schott et S. Hayes interjectis) enumeratae novaeque descriptae. Memoirs of the American Academy of Arts and Science, new series 8: 193-220. 1860 